Acta Theriologica 37 (3): $301-317,1992$.

PL ISSN $0001-7051$

BISONIANA 110

\title{
Free ranging European bison in Borecka Forest
}

\author{
Zbigniew A. KRASIŃSKI and Małgorzata KRASIŃSKA
}

Krasiński Z. A. and Krasińska M. 1992. Free ranging European bison in Borecka Forest. Acta theriol. 37: $301-317$.

This paper presents the history, herd structure, distribution and habitat preference of the free ranging herd of European bison Bison bonasus (Linnaeus, 1758) in Borecka Forest, north-east Poland. Herd numbers fluctuated between 48 and 71 individuals from 1976 - 1991 through population regulation by sport shooting and removal of culls. During the snow free period the bison were distributed in a 8700 ha part of the forest area with an actual density of $6-8$ individuals per 1000 ha. The coefficient of birth was $18.2 \%$ on average and the mortality coefficient was $4.3 \%$. The structure of the population varied because animals were introduced, and removed by hunting. The average size of mixed groups was $11.0 \pm 10.6$ individuals and the groups of bulls averaged $1.44 \pm 0.6$ animals. Solitary bulls compriseed $68.5 \%$ of observations. Mixed groups formed one large aggregation around supplemental feeding sites in winter; adult bulls wandered separately. Bison preferred deciduous forests $(96.7 \%$ of all forest observations) especially stands older than 20 years $(87.5 \%)$ and occasionally thickets $(12.5 \%)$. To a large degree they used open areas as feeding grounds $(37 \%)$ although they preferred the forest $(63 \%)$. We compared the basic data of the European bison's ecology in Borecka and Białowieża Forests and found that group type, size, and spatial structure were characteristic features of this species. The bison showed similar population trends in different environments of lowland forests but their use of forest types varied according to diversity and food abundance.

Białowieża National Park, 17-230 Białowieża (ZAK) and Mammal Research Institute, Polish Academy of Sciences, 17-230 Białowieża, Poland (MK)

Key words: Bison bonasus, ecology, Borecka Forest, Poland

\section{Introduction}

Borecka Forest is currently one of the five centres for free-ranging European bison Bison bonasus (Linnaeus, 1758) in Poland. It is situated within the European bison's range where this species existed historically in its natural condition until the middle of the 18th century. The last bison was killed in East Prussia in 1775 by a poacher (Hagen 1819, refered to after Bojanus 1827). European bison of the lowland-Caucasian (LC) line have been bred here from 1962 to 1969, and since 1970 - the bison of the lowland (L) (Białowieża) line.

The formation of a second free-ranging herd of bison in Poland (after Białowieża Primeval Forest) provided the opportunity to carry out comparative research in different environments of lowland forests. Dynamics of the bison population were 
observed since establishment in Borecka Forest in 1962. Data on herd structure, spatial distribution and habitat selection were collected periodically between 1982 and 1984. The health condition of the bison was assessed every winter between 1985 - 1991.

This paper documents the establishment of this herd, the dynamics of its development, social structure, spatial distribution and the utilization of the environment. We also evaluated of methods used in the management of this population. Some elements of the ecology of this herd were compared to the European bison population in Białowieża Forest.

\section{Characterization of the forest complex}

Borecka Forest is located in north-east Poland in the Mazurian Lake District. It is over 22 thousands ha in size with an area of about 18 thousands ha of close forest complex. Near Walisko Lake there is a bison reserve of about $60 \mathrm{ha}$; from 1956 - 1985 bison were kept fenced in this reserve (Krasiński 1986).

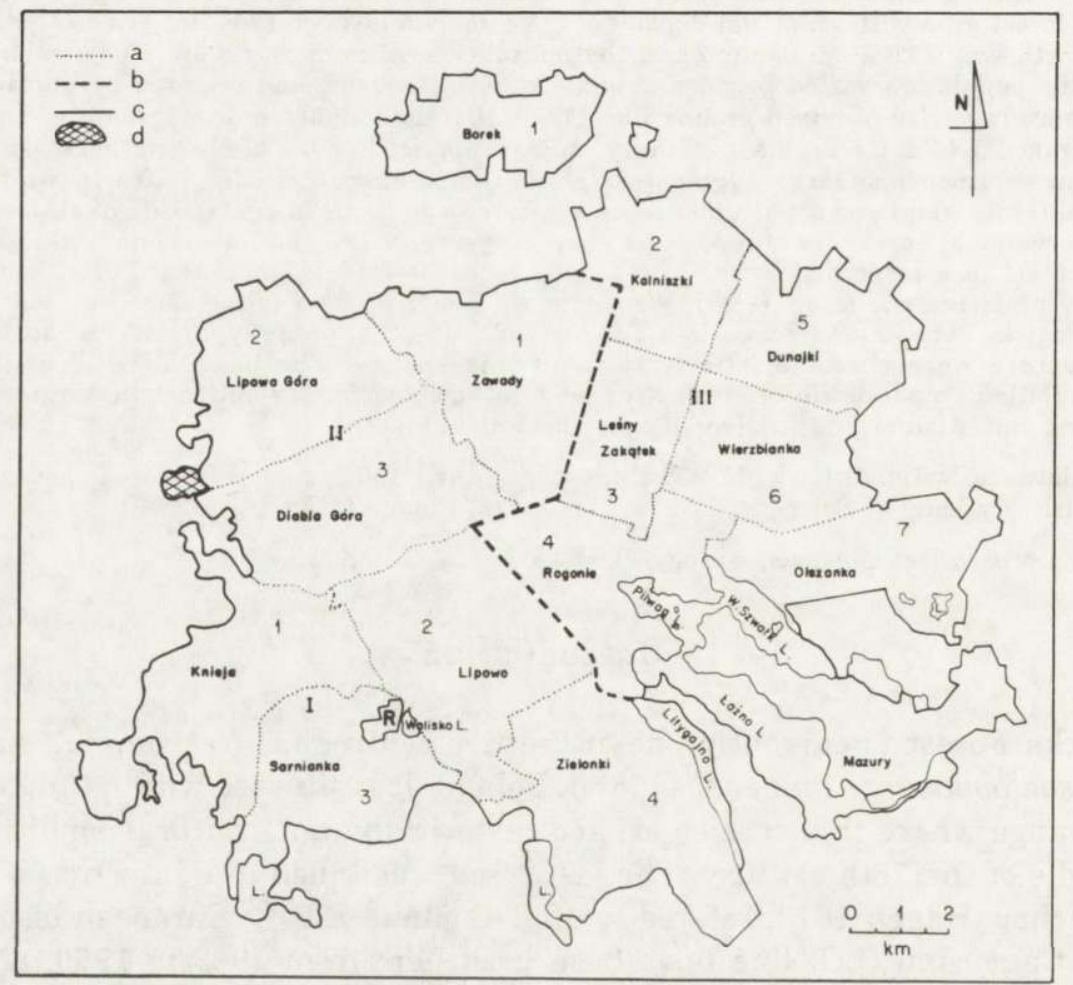

Fig. 1. Map of Borecka Forest. I, II - Forest Inspectorate of Borki, III - Forest Inspectorate of Czerwony Dwor, L - Lakes, R - Bison reserve. Numerals and names - indicate the number and name of Forest Administration District (FAD), a - borders between FADs, b - border between Forest Inspectorates, $\mathrm{c}-$ border of the forest complex, $\mathrm{d}-$ farmland. 
This part of Poland has the lowest average annual air temperature of $+5.9^{\circ} \mathrm{C}$. The average total rainfall per year amounted to $658 \mathrm{~mm}$ and the average air moisture $-82 \%$ (Polakowski 1961).

Forests are distinguished for their various habitats species associations (Polakowski 1961). The main components of this forest are spruce Picea abies and, in the humid areas, alder Alnus glutinosa and ash Fraxinus excelsior. Spruce usually occurs with hornbeam Carpinus betulus, oak Quercus robur and lime Tilia cordata and sometimes with pine Pinus silvestris. These predominant species are accompanied by birch Betula verrucosa, aspen Populus tremula, maple Acer platanoides and larch Laryx decidua. Spruce is the major component of the tree stands and the remaining species occur more abundantly only locally. Spruce is declining in the central and southern part of the forest complex where deciduous species, mainly hornbeam, oak and lime are becoming more significant. Deciduous habitats cover $77.3 \%$ of the western part of Borecka Forest; this part is a main refuge of the bison. Dominant species are spruce $(35.4 \%)$, oak (19.04\%), birch $(16.3 \%)$ and alder $(11.9 \%)$.

The high stands are chacterized by a rich undergrowth mainly hazel, and to a lesser extent rasberry and mountain ash. This forest also has an abundant harbaceous layer.

\section{Materials and methods}

All available information concerning the herd of European bison in Borecka Forest from 1962 until 1991 was considered for this paper. This included documents from the European bison breeding centre in Borki and personal information from its manager and the forest and wildlife managers of the Forest Inspectorates of Borki and Czerwony Dwor.

Two stages of development of the herd were apparent. The first one comprised the lowlandCaucasian (LC) bison bred there between the years 1962 - 1969; and the second comprised only lowland (L) bison from 1970 - 1991.

The population size of European bison was assessed every year in the winter (January, February) using direct observations. Not all the data concerning the numbers of animals agree with the size of the population shown annually in the European Bison Pedigree Book. This may result from an incorrect record of the European bison.

Some ecological questions on European bison in Borecka Forest were investigated during seven two-week expeditions from 1982 through 1984. Direct observations on the bison were made from sunrise until 10.00 a.m., and from 3.00 p.m. until sunset. The total number of direct observations amounted to 140 (706 bison). The size and composition of the groups, the place where bison were found, type of forest and behaviour of the bison were recorded. The same methods were used as in Białowieża Primeval Forest (Krasiński 1978).

From 1985 through 1991 three to five day periods of observations on the population number, spatial structure and health condition of the bison were recorded $2-3$ times a year.

The area inhabited by the bison was delineated by administrative divisions (Fig. 1) because certain compartments in the forest were irregular and difficult to identify.

\section{Lowland-Caucasian line bison, 1962 through 1969}

On the 5th of May, 1962 five $(3,2) *$ European bison were released from the fenced reserve. A total of $14(10,4)$ lowland-Caucasian line bison were introduced in Borecka Forest between 1962 and 1966 (Table 1).

Eight $(4,4)$ calves were born between 1962 and 1968. One late birth (December, 1968) and one case of natural death (male PUZON, Pedigree No 1457, in 1968) occurred. The old bull PUSZCZAN fathered of the first three calves; the fathers of

\footnotetext{
* Numbers in brackets indicate numbers of males and females respectively.
} 
Table 1. Register of ancestor of the free-living lowland-Caucasian line population of European bison in Borecka Forest. Popielno - Institute of Genetic and Animal Breeding, Polish Academy of Science, Experimental Station in Popielno.

\begin{tabular}{|c|c|c|c|c|c|c|c|}
\hline Year & $\mathbf{n}$ & Sex & $\begin{array}{c}\text { Pedigree } \\
\text { No }\end{array}$ & Name & $\begin{array}{l}\text { Age } \\
\text { (yrs) }\end{array}$ & Origin & $\begin{array}{l}\text { Date of } \\
\text { release }\end{array}$ \\
\hline \multirow[t]{5}{*}{1962} & $5(3,2)^{* *}$ & M & 825 & PUSZCZAN & 11 & Borki Reserve & 5. 05.1962 \\
\hline & & $\mathrm{F}$ & 937 & PUSZKA & 8 & & \\
\hline & & M & 1208 & PUZOR & 3 & & \\
\hline & & $\mathrm{F}$ & 1285 & PUZA & 2 & & \\
\hline & & M & 1355 & PUSZYSTY & 1 & & \\
\hline \multirow[t]{2}{*}{1963} & $2(1,1)$ & M & 1457 & PUZON & 1 & Borki Reserve & 20. 06.1963 \\
\hline & & $\mathrm{F}$ & 1460 & PUNITKA & 1 & & \\
\hline 1964 & $1(1,0)$ & M & 1203 & PUNIT & 5 & Popielno & 12. 09.1964 \\
\hline 1965 & $1(1,0)$ & M & 1359 & PUZYN & 4 & Borki Reserve & 14. 04.1965 \\
\hline \multirow[t]{5}{*}{1966} & $5(4,1)$ & M & 1868 & PUGINAL & 1 & Borki Reserve & 30. 04.1966 \\
\hline & & M & 1688 & PUZOT & 2 & & 30. 04.1966 \\
\hline & & M & 1684 & PUZONIT & 2 & & 30.04 .1966 \\
\hline & & $\mathrm{F}$ & 1695 & PUNIATA & 2 & & 30. 09. 1966 \\
\hline & & M & 1869 & PUZOL & 1 & & 30. 09. 1966 \\
\hline
\end{tabular}

Table 2. Register of ancestor of the free-living lowland line population of European bison in Borecka Forest. ${ }^{*}$ European bison from free breeding have no names - only a registration number.

\begin{tabular}{|c|c|c|c|c|c|c|c|}
\hline Year & $\mathrm{n}$ & Sex & $\begin{array}{c}\text { Pedigree } \\
\text { No }\end{array}$ & Name* & $\begin{array}{l}\text { Age } \\
\text { (yrs) }\end{array}$ & Origin & $\begin{array}{l}\text { Date of } \\
\text { release }\end{array}$ \\
\hline \multirow[t]{5}{*}{1970} & $5(2,3)^{* *}$ & M & 1859 & РОTOK II & 5 & Białowieża Reserve & 23. 06.1970 \\
\hline & & $\mathrm{F}$ & 1863 & POLA & 5 & & \\
\hline & & $\mathrm{F}$ & 1985 & POSOKA & 4 & & \\
\hline & & $\mathrm{F}$ & 2109 & POLUDA & 3 & & a \\
\hline & & M & 2111 & PODDANY & 3 & & \\
\hline \multirow[t]{10}{*}{1971} & $10(5,5)$ & M & 2269 & PLED & 3 & Pszczyna Reserve & 19. 08.1971 \\
\hline & & M & 2252 & PONTON & 3 & Białowieża Reserve & 20. 01.1971 \\
\hline & & M & 2255 & POKER & 3 & Białowieża Forest & 23. 01.1971 \\
\hline & & $\mathrm{F}$ & & 267 & 3 & & \\
\hline & & $\mathrm{F}$ & & 268 & 3 & & \\
\hline & & M & & 269 & 3 & & \\
\hline & & M & & 303 & 2 & & \\
\hline & & $\mathrm{F}$ & & 231 & 4 & & \\
\hline & & $\mathrm{F}$ & & 275 & 3 & & \\
\hline & & $\mathrm{F}$ & & 366 & 1 & & \\
\hline
\end{tabular}

** Numbers in brackets indicate numbers of males and females respectively. 
the others were PUSZYSTY and PUNIT. These bulls were observed in the herd during the rutting season. The fifteen year old male PUSZCZAN was shot on the 7 January 1966. This was the first sport-shooting of the European bison in Poland after many years. The annual sport-shooting of bison in Borecka Forest began 10 years later.

With reestablishment of European bison in Poland it was assumed that bison of the lowland line should inhabit central and north Poland, and those of the lowland-Caucasian line, south-east Poland (eastern Carpathians). Accordingly, lowland-Caucasian bison in Borecka Forest were replaced by pure lowland bison. By using additional feeding close to the fenced reserve all of the lowland-Caucasian line were captured in two years. The first group of $13(5,8)$ individuals (all the cows and young) was enclosed in December, 1968. The other 6 bulls were enclosed in March, 1969. These bison then were sent to other breeding centres in Poland (Smardzewice, ZOO).

Since the establishment the free-ranging herd, bison have ranged through the forest districts of Knieja, Sarnianka, Diabla Góra, Lipowa Góra and Lipowo (Fig. 1) as a single unit during the snow free period. After 10 years of age did the old bull PUSZCZAN wandered alone, often near the fenced reserve. During the rutting season he joined the herd. In 1964 PUSZCZAN was 14 years old, and stopped joining the herd during the rut. His place was taken by the five year old bulls.

During the winter additional food, mainly hay, was given to the bison in the feeding rack situated near the reserve. Cows, young and calves composed one group. The adult males only sporadically visited the feeding site together with females and young. In 1967 a group of eighteen came to the feeding site when the first snow fell. They fed on hay every day. From among five adult bulls only the strongest six year old PUSZYSTY joined the mixed group. The other four bulls stayed far from the herd. Two of them, the youngest four and five year olds wandered together in Lipowo and Sarnianka districts (Fig. 1). The other two were solitary, the six year old bull stayed within the Lipowa Gora district, and the eight year old wandered in Zielonki district. These bulls used food set aside for deer. These observations suggest that the typical elements of spatial structure for the species Bison bonasus were developed in the early years of the free-ranging herd existence in Borecka Forest.

\section{Lowland line bison during the yerrs 1979 - 1991}

\section{Characteristics of the population}

After removal of LC line European bison from Borecka Forest in 1969, a group of $5(2,3)$ lowland line bison brought from Białowieża on the 23rd June, 1970 were introduced. The next $10(5,5)$ bison aged 1 and 5 years were released in 1971 . Since then the population of lowland line European bison has been composed of $15(7,8)$ individuals. Of these $7(2,5)$ were from the breeding reserve in Białowieża, 
$7(3,4)$ were from the free herd in Białowieża Primeval Forest and 1 male was bison from the enclosed breeding centre in Pszczyna (Table 2). During the years 1972 and 1973 no introduction were made.

Sport-shooting of the European bison began in Borecka Forest in 1975. Thereafter animals from other breeding centres were brought to Borecka Forest because the resident population could not provide for the hunter's needs. In 197523 (16, 7) bison were brought from Białowieża; these were between 6 and 22 years old. Introductions continued in the following years. The greatest number of European bison - $36(13,23)$ individuals - were introduced in 1976. During the years 1980 - 1991 introductions were reduced to $1-7$ individuals per year, and ceased after 1984. The total number of European bison brought to Borecka Forest from Białowieża amounted to $119(67,52)$ individuals and of this $104(61,43)$ originated from the free herd and $15(6,9)$ from captive breeding. Individual bison were also delivered from other breeding centres, the greatest number being from Pszczyna (11 individuals). Most European bison from other breeding centres were shot in the same season of introduction. For this reason introductions did not have much effect upon population of the Borecka Forest bison.

Between 1976 and 1991 the population numbers fluctuated between 49 and 71 animals (Fig. 2). The first bison was born in 1970 and during the years $1970-$ $1991,168(83,85)$ calves were born.

The coefficient of births (percentage of calves to the population size) amounted to $18.2 \%$ on average from 1972 through 1991 , and fluctuated between $35.7 \%$ in 1976 to $5.2 \%$ in 1988 . The coefficient of fecundity (percentage of the number of

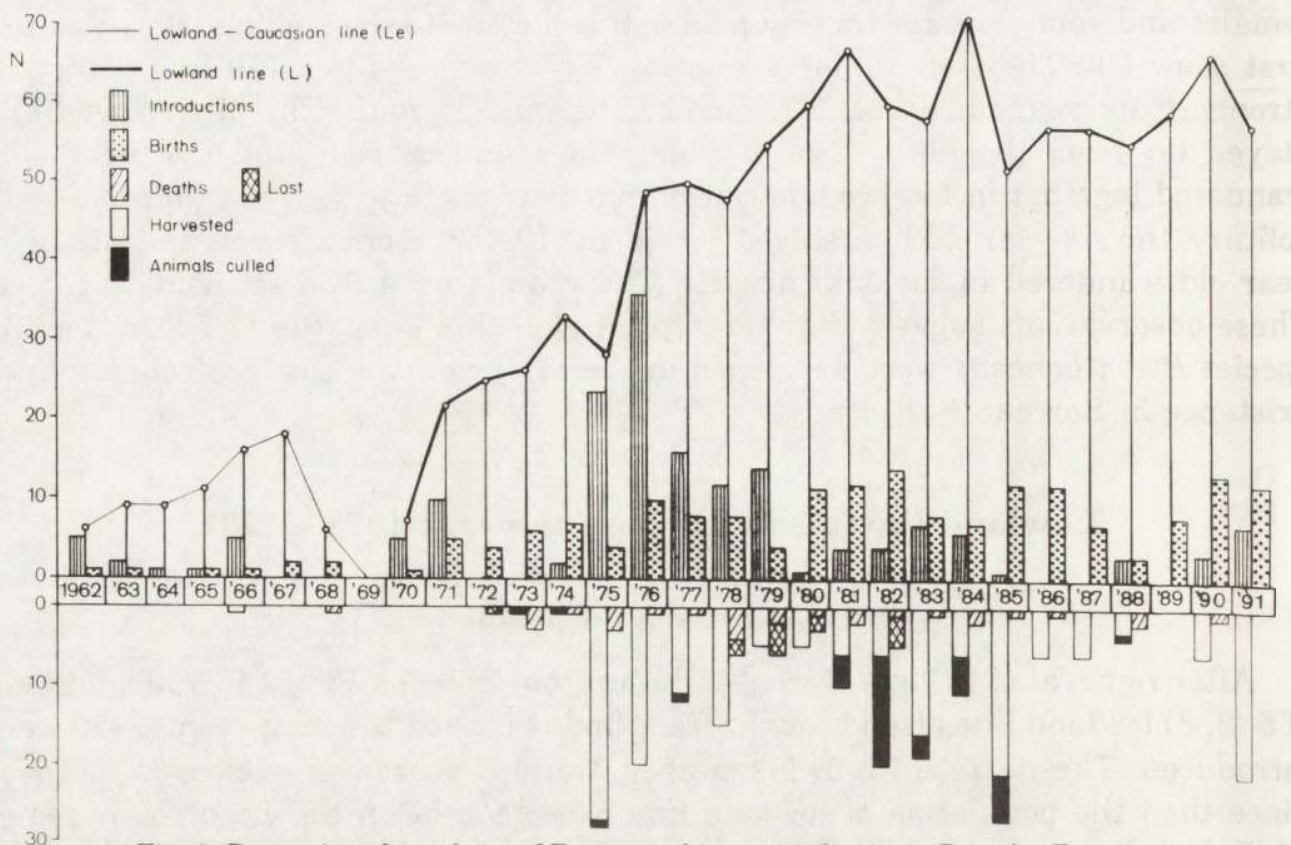

Fig. 2. Dynamics of numbers of European bison population in Borecka Forest. 
calves to the number of cows capable of reproduction) could not however be calculated because of the lack of appropiate data.

Natural mortality was minor. Only single deaths were observed, although some individuals were recognized as missing. Taking into account the number of all of them, a coefficient of mortality for the years 1972 - 1991 amounted on average to $4.3 \%$ per year.

Regulation of population size in Borecka Forest was carried out through sport shooting and by elimination from breeding (selective and reductive shooting). Sport shooting started in 1975; in this year hunters shot $27(19,8)$ bison. According to records $154(93,61)$ bison were shot for sport in Borecka Forest from 1975 thorough 1989 , for $10.3(1-27)$ individuals on average per year. This large number of sport-removed bison was possible only due to the permanent introduction of bison from Białowieża Primeval Forest.

Elimination from breeding of the bison in Borecka Forest was sporadically performed till 1981. Most often weak bison, late born calves, visibly sick or defective animals and those inhabited that areas beyond the forest were selected to be eliminated. After 1981 elimination became more frequent as an additional method for regulating numbers. The total number of eliminated bison amounted to $35(17,18)$ individuals during the years $1970-1991$. Results of autopsies indicated the healh condition of the animals. Only 2 individuals ( 6 and 7 months old) eliminated did not show visible pathological changes. Most often changes were caused by parasites (helminthoses of the lungs and distomiasis) were found in $64.3 \%$ of the animals. Calves up to one year old were most often infected with verminous disease of the lungs. The other changes observed were related to injuries caused by snares. Two males 1.4 and 3 years old showed disease of the sexual organs of unknown etiology. Selected bison often proved to be in good condition although they had great pathological changes. This indicated to the ability of individual bison to limit the spread of pathological processes.

\section{Structure of the population}

Population structure (adult bulls, adult cows, young of $2-3$ years old and calves) was not recorded every year in Borecka Forest. The main group composed of the individuals born into and permanently living in the population did not change even though some of these were eliminated. Many of the introduced animals were shot in the same hunting season, minimizing their effect upon the population structure. However, it was apparent that there were periods when unfavourable changes occurred in the population structure as a result of excessive hunting. For example: in the beginning of 1983 a decrease in the number of cows over 4 years old ( $28 \%$ of population) and a simultaneous increase in young (33\%) was observed. The proportion of calves and bulls did not show change. A reduction in shooting and additional selected elimination allowed for correction of deviations in the structure of the European bison population in Borecka Forest. At the end of 1987 the population structure was more approximate to that of lowland bison 
Table 3. Structure of the European bison population in Borecka Forest in 1987 and in Białowieża Forest. * Krasiński 1978.

\begin{tabular}{|c|c|c|c|}
\hline \multirow{2}{*}{ Group of animals } & \multicolumn{2}{|c|}{ Borecka Forest } & \multirow{2}{*}{$\begin{array}{c}\text { Białowieża Forest* } \\
\%\end{array}$} \\
\hline & $\mathbf{n}$ & $\%$ & \\
\hline Bulls $>4$ yrs & 10 & 17.2 & 25 \\
\hline Cows $>4$ yrs & 24 & 41.4 & 35 \\
\hline Juveniles $2-3$ yrs & 17 & 29.3 & 25 \\
\hline Calves up to $1 \mathrm{yr}$ & 7 & 12.1 & 15 \\
\hline Total & 58 & 100.0 & 100 \\
\hline
\end{tabular}

Table 4. Size of mixed groups of European bison in Borecka Forest in the summer period between 1982 - 1984. $\mathrm{n}$ - number of herds observed.

\begin{tabular}{lcccrr}
\hline Year & n & Min & Max & Avg. & SD \\
\hline 1982 & 19 & 2 & 44 & 15.8 & 13.1 \\
1983 & 12 & 3 & 25 & 10.4 & 7.0 \\
1984 & 11 & 3 & 35 & 8.9 & 9.3 \\
$1982-1984$ & 42 & 2 & 44 & 11.8 & 10.6 \\
\hline
\end{tabular}

Table 5. Size of bull groups of European bison in Borecka Forest in the summer period between $1982-1984$. $n$ - number of groups or single animals observed.

\begin{tabular}{lccccc}
\hline Year & $\mathrm{n}$ & Min & Max & Avg. & SD \\
\hline 1982 & 22 & 1 & 4 & 1.50 & 0.80 \\
1983 & 14 & 1 & 4 & 1.64 & 0.92 \\
1984 & 18 & 1 & 3 & 1.22 & 0.54 \\
$1982-1984$ & 54 & 1 & 4 & 1.64 & \\
\hline
\end{tabular}

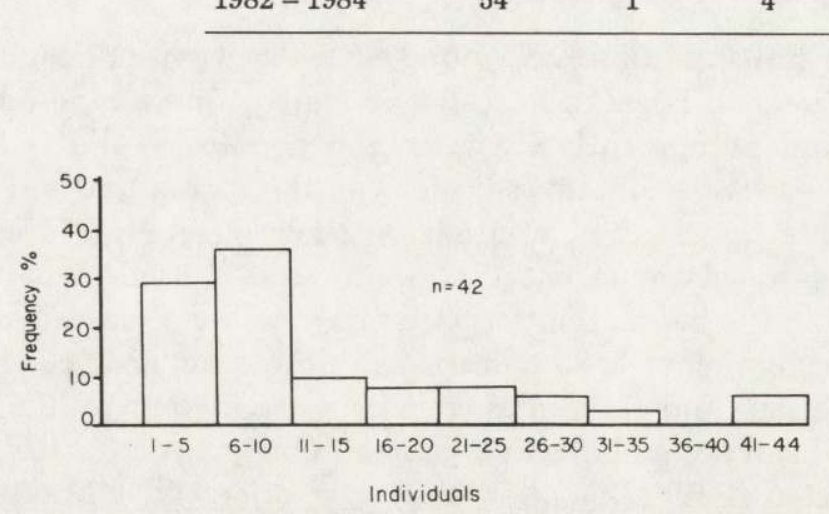

Fig. 3. Average size of mixed groups for summer periods 1982 - 1984.

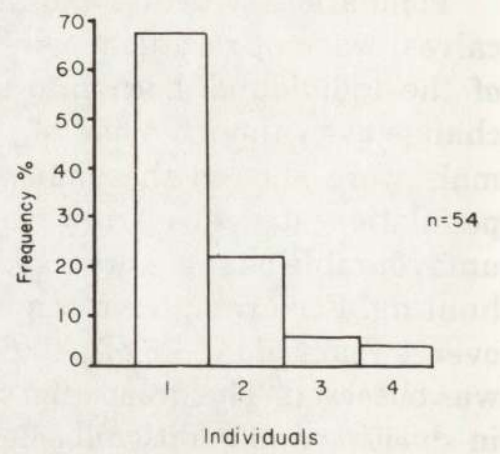

Fig. 4. Average size of bull groups for summer periods $1982-1984$. 
in Białowieża Primeval Forest, in spite of a low proportion of adult males (Table 3).

$$
\text { Reproduction }
$$

The European bison calved from May to September in Borecka Forest, although on rare occasions calves were born in late autumn. Rutting took place in August and September and was dominated by bulls over 6 years. Bulls over 13 years old were not observed as participants in the rut. They usually wandered alone giving way to younger bulls.

\section{Herd structure}

Seasonal changes in vegetation fostered the natural groupings of bison. European bison in Borecka Forest created two types of groups - mixed and bull groups - during the snow free period. From 1982 until 1984 the average size of the mixed groups was $11.8 \pm 10.6$ (Table 4). Groups composed of 10 individuals comprised $64 \%$ of the observations (Fig. 3). The average size of the bull group was $1.64 \pm 0.76$ individuals (Table 5 ). Solitary bulls constituted $68.5 \%$ of all bull group observation and pairs $-22.2 \%$ (Fig. 4 ).

The size and composition of both of these types of groups were not constant, and changed often during the snow-free season. In Borecka Forest a mixing of the groups into one large aggregation near the supplemental feeding site in winter was always observed. This began in late autumn.

The adult bulls wandered separately in single or small groups during the winter and used feeding places set aside for deer. Only a few bulls were observed in mixed groups in this season.

\section{Spatial structure \\ The snow-free season}

European bison did not utilize the whole area of Borecka Forest. They mainly used the western part of the Forest around the breeding reserve. This area comprised of 7500 ha including the forest districts of Knieja, Lipowo, Sarnianka, Diabla Góra and Lipowa Góra (Fig. 5). The eastern part was inhabited by bulls and sporadically by mixed groups. The area inhabited by the bison amounted to 1200 ha, situated mainly in Kalniszki, Dunajki, Rogonie and Olszanka districts. The total area of intensive habitat used by the bison in Borecka Forest amounted to 8700 ha (Fig. 5).

\section{Winter season}

In the late autumn the bison formed one mixed aggregation feeding on rape and winter-crop cultivations near Diabla Góra (Fig. 1). When permanent snow cover occurred this group came to the feeding sites situated near the breeding reserve (Fig. 5). Most of the bulls stayed outside the mixed group using the food set aside 


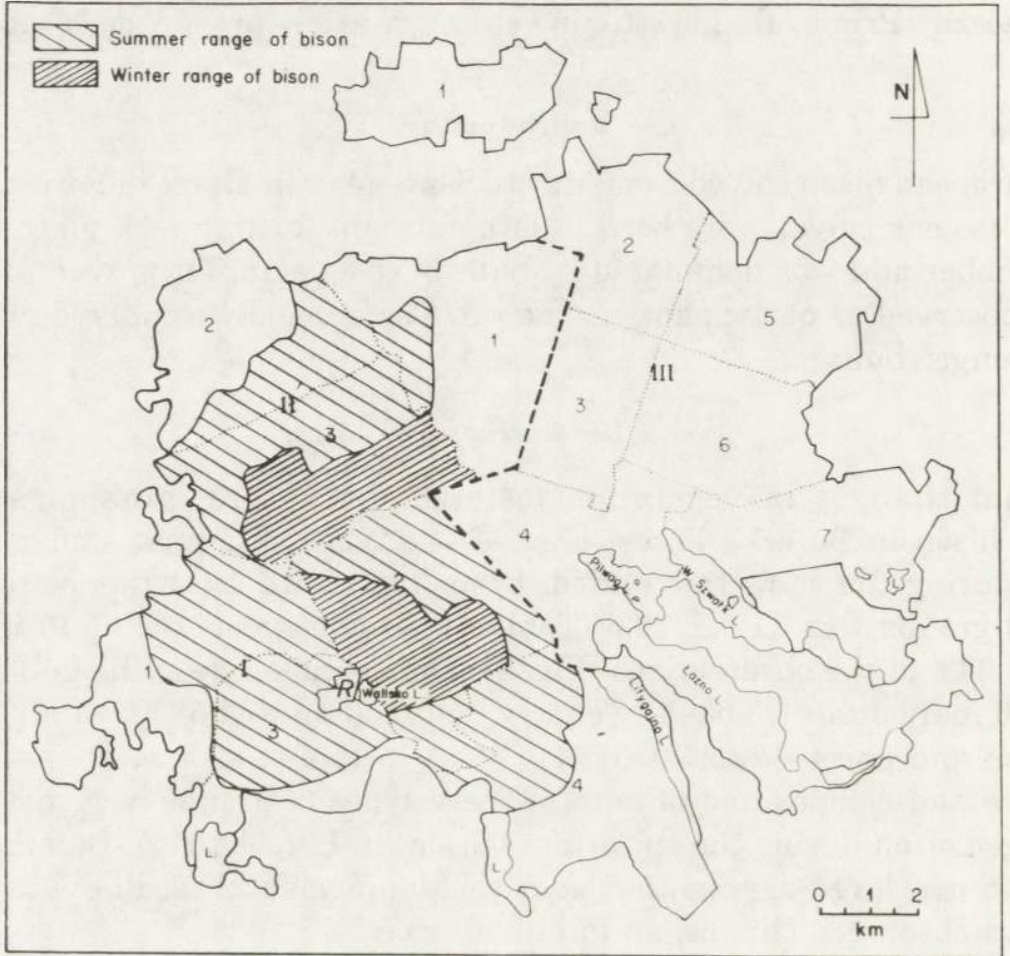

Fig. 5. Spatial structure of European bison in Borecka Forest. 1 - summer range, 2 - winter range, R - bison reserve. For other explanation see Fig. 1.

for deer in the Forest Inspectorate of Borki. About 10\% of bulls inhabited areas far away from this group in the Forest Inspectorate of Czerwony Dwór (Fig. 1).

\section{Migrations}

No seasonal migrations of bison groups to other forests were observed, but there were some wandering of solitary bulls (Fig. 6). The cases were as follows:

- The appearance of a solitary bull in the Forest Inspectorate of Gołdap (Romincka Forest) $30 \mathrm{~km}$ northward from Borecka Forest in the beginning of the 1970 s. This bull was shot in 1973 . The autopsy recorded a leg injury as a result of a snare and caused permanent limping.

- In 1975 one bull wandered $150 \mathrm{~km}$ south-west from Borecka Forest near Nidzica. This bull was shot.

- In 1981 a single bull was observed in a small woodlots in the middle of a cultivated area near Bakałarzew, $40 \mathrm{~km}$ from Borecka Forest. After the bison was shot it was ascertained it had caught purulent pneumonia.

- In 1987 a bull again appeared in Romincka Forest and lived there till 1989 (Fig. 6). 


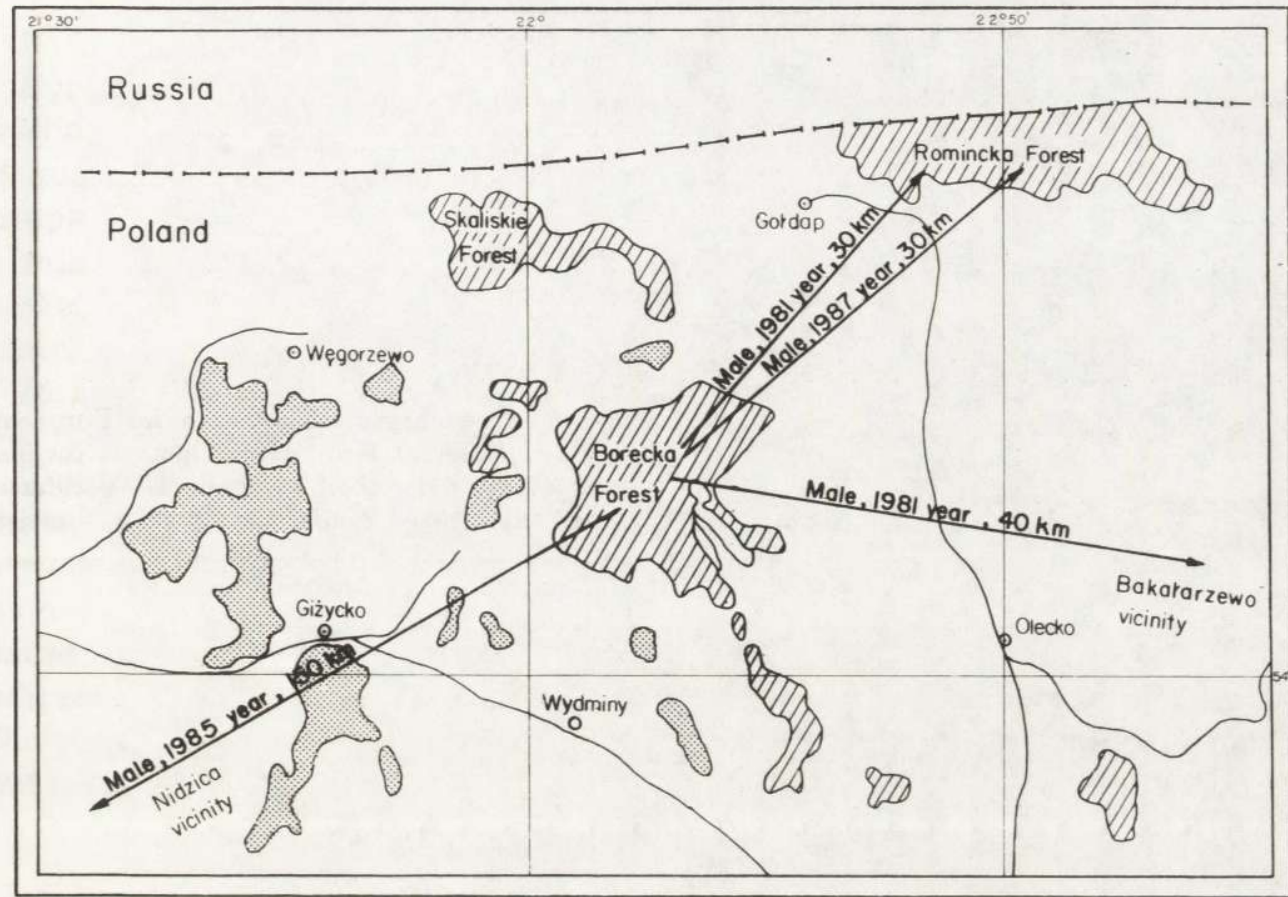

Fig 6. Migration of European bison bulls from Borecka Forest. Shaded are forest, dotted are lakes.

\section{Density}

The average density of the bison in Borecka Forest amounted to 3.3 to 3.9 individuals per 1000 ha for $60-70$ animals, in the whole of the forest complex. However, the true density calculated for the area naturally inhabited by the bison $(8700 \mathrm{ha})$, amounted to $6.9-8.0$ individuals per 1000 ha. Because the bison did not inhabit all the accessible areas farther increase in their numbers would have caused a larger density and greater pressure on the environment.

\section{Habitat utilization}

Both the mixed group and the bull group's grazing pattern was circular over time; they returned to the place previously utilized some time later. This foraging behaviour prevented overgrazing of forest habitats and allowed the regeneration of the herb layer (cf Krasińska et al. 1987).

The data obtained on food habitats with seasonal environmental changes were not complete: because of this the seasonal changes in selectivity of habitats were not fully known.

During the snow-free season the bison used forest environments more $(62.7 \%)$ compared to open areas $(37.1 \%$, Fig. 8$)$. They preferred deciduous forests $(96.7 \%$ 


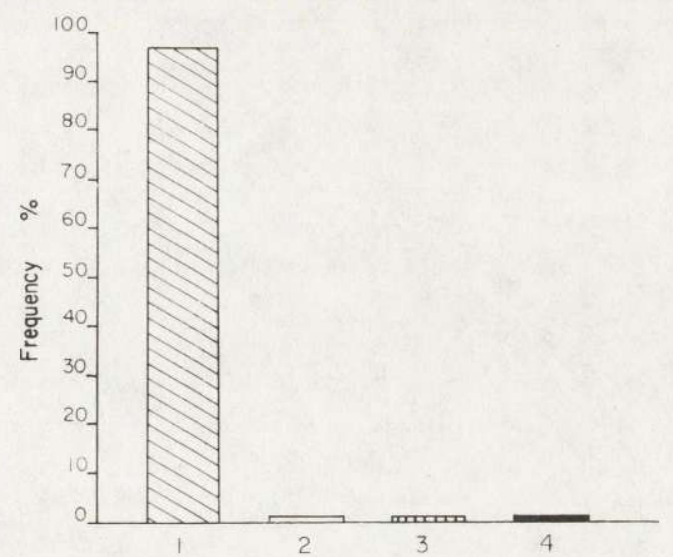

Fig. 7. Frequency of observations of European bison in different forest types in areas covered with stands older than 10 years. 1 - deciduous forest, 2 - mixed coniferous forest, 3 - moistconiferous forest, 4 - alderwoods.

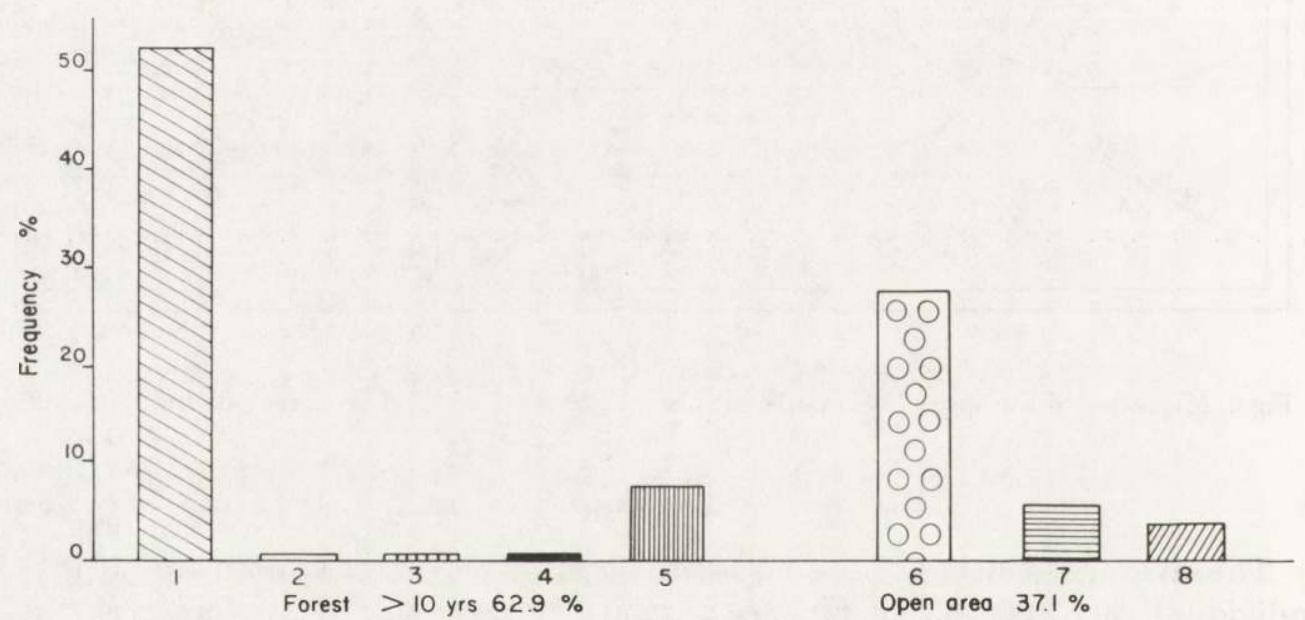

Fig. 8. Habitat preferences of European bison in Borecka Forest. 1 - deciduous forest $>20$ yrs old, 2 - mixed coniferous forest $>20$ yrs old, 3 - moist coniferous forest $>20$ yrs old, 4 - alderwoods $>20$ yrs old, 5 - deciduous forest $10-20$ yrs old, 6 - meadows, 7 - clearcuts and plantations up to $10 \mathrm{yrs}$ old, 8 - fields.

of forest observations) and were very rarely observed in coniferous forests and alderwoods (Fig. 7). They fed mainly in forests over 20 years old $(87.5 \%$ of all forest observations). Observations where bison fed in open areas included meadows $(75 \%)$, clearctus and young plantations up to 10 years of age (15.4\%), and cultivated fields $(9.6 \%)$.

Cultivated fields (rape, winter crop) were frequented in early spring and late autumn. During this time considerable damage resulted mainly from trampling.

The refuge of the European bison (Fig. 5) was dominated by lime, oak, hornbeam and ash stands, and incorporated a large number of mowed meadows. This ensured a rich and diversified feeding ground. 
Supplemental winter feeding and habitat use

Supplemental winter feeding was undertaken permanently in Borecka Forest. Feeding sites were situated near the reserve. Some problems occurred with adequate hay; accordingly bison also were fed silage, pasturable cabbage and pumpkin. As a result of bulky fodder a nutritional deficiency may have occurred, because we observed an increase in the debarking of oak and oak-hornbeam thickets near the places of winter concentration. Even the big trees like ash were debarked in these areas.

In Borecka Forest the bison also used the food set aside for deer and wild boars to a relatively high degree.

Towards the end of winter when the snow disappeared bison left the supplemental feeding sites and moved to the cultivated fields causing damage. They also intensively debarked trees in this time. To prevent such damage almost half of the herd was enclosed in the reserve from the end of winter until the herbaceous plants were abundant in the forest. Experiments during the years from $1982-84$ indicated a weakened conditions of the bison and an increase in lung parasites (Dictyocaulus sp.). This method of preventing damages in the tree stands was controversial and ceased after 1986.

\section{Discussion}

The stands of Borecka Forest are unique among the heterogenous habitats (Polakowski 1961). Such a mosaic of habitats does not occur in the other great forests of Poland (Dzięciołowski 1991) and as a result this forest is very important for large herbivores. Also, meadows are interspersed within the forest and are very important feeding places for the bison. Research undertaken by Dzięciołowski (1991) showed a high recruitment rate and a low mortality in ungulate populations, indicating a high quality of habitat for five ungulate species: European bison, elk, red deer, roe deer and wild boar.

For comparison with Borecka Forest mosaic of forest types also occurs in Białowieża Primeval Forest. The most important are deciduous oak- hornbeamlime stands and their contribution to the total forested area amounts to $26.6 \%$ (Pucek et al. 1975). The ungulate community also includes bison, elk, red deer, roe deer and wild boar. In the last few years the foraging areas apper to have deteriorated compared to the feeding requirements of bison. Open area with an abundant ground cover decreased in amount as a result of discontinued clearcutting, reforestation or fencing of most feeding glades, and discontinued mowing of forest meadows. An increase in extent of forest habitat penetration, and changes in biotope preferences resulted from these processes (Krasińska et al. 1987). Changes were also increased by the drop in the level of ground water during the years 1987 through 1991. In Białowieża Primeval Forest at the end of the 1980s we observed, simultaneously, high numbers of ungulates, especially European 
bison and red deer. We were interested if enviromental differences in the two forest complexes would influence the ecology of the bison.

The basic structure units of the bison population were mixed groups and groups of bulls. The size of these groups was similar in the 50 individual population in Borecka Forest and in the 250 individuals in Białowieża Forest. About $90 \%$ of mixed groups included of no more than 20 individuals (Krasiński 1978, Senger 1983, Krasińska et al. 1987). It might be supposed that this is the optimum size of the European bison herd living in the lowland forests of Poland, and that this size is characteristic for this species. There were more bulls wandering solitary in Borecka Forest $(68.7 \%)$ than in Białowieża Primeval Forest (62\%), but this might be a result of too few number observations performed mainly during the summer and the rutting season. An increase in solitary males during the rut in Białowieża Primeval Forest was observed (Krasińska and Krasiński 1991).

Both populations had similar birth-rates. The coefficient of births amounted to $18.2 \%$ on the average in Borecka Forest and $18.5 \%$ in Białowieża Primeval Forest. Natural mortality was low in both populations (4.3\% and $3 \%$ respectively). Supplemental feeding in winter and selective-rec'uctive shooting certainly contributed to a low mortality in both populations. However no contemporary existing populations of European bison can expend indefinitely, without regulation of its numbers by man.

Large mixed aggregations near the supplemental feeding sites were observed in both populations during snow and frost period of winter. The number and size of these groups also depended upon the size of the population and the number of feeding sites. There was one aggregation in Borecka Forest, but two aggregations were observed in Białowieża Primeval Forest. Observations carried out during the snow-free winters of $1988 / 1989$ and $1989 / 1990$ confirmed that permanent snow cover a.l systematic'supplemental feeding influenced an increase of the group size in winter, taking into account also the decreased mobility of bison during this period.

The rutting and calving seasons occurred in the same time of year in both populations. One out-of-season calving was observed in December in Borecka Forest; no similar cases were seen in Białowieża Primeval Forest.

European bison did not inhabit all the accessible areas of forest in Borecka Forest nor in Białowieża Primeval Forest. The true density amounted to $6.9-8.0$ individuals per 1000 ha in Borecka Forest, and was twice as high in Białowieża Primeval Forest (16.3 individuals per 1000 ha) (Z. A. Krasiński, in litt).

Movements of single bulls to the other forest areas in Borecka Forest were observed. Wandering bulls may be looking for new areas for spreading the population; they also may be in poor condition and unable to compete with the other males during the rutting season.

Results of our research on habitat utilization by European bison agree with conclusions of Dzięciołowski (1991) who also presents the seasonal aspect. European bison prefer feeding grounds of the forests but also use feeding grounds 
of open areas to a large extent. Biotope preferences of bison in Borecka Forest were alike to preferences observed in Białowieża Primeval Forest up to mid 1970s (Krasiński 1978). Since these years an increase has occurred in the penetration of forest types in Białowieża Primeval Forest as a result of a decrease in acreage of open areas. Deciduous forests are still preferred but with seasonal increase of penetration in mixed coniferous forests (Krasińska et al. 1987).

Preliminary information suggests that Borecka Forest offers the bison higher quality foraging than does Białowieża Primeval Forest. Mowed meadows which are easily reached by the bison during the growing season are very important. The lack of such meadows and the scarcity of managed glades reduces the amount of high quality foraging habitat for bison in Białowieża Primeval Forest.

The low visitation by people of Borecka Forest is another advantage compared to Białowieża Primeval Forest. European bison are more wild in Borecka Forest and usually flee from humans.

Comparing these two populations we can say that the features of the species Bison bonasus are alike : types of groups, numbers of them and spatial structure are similar in different lowland forests in Poland. However usage of the forest environment is changeable depending on habitat differences and food supply.

There are two regulatory methods for limiting free living bison numbers in Poland. Selective-reductive shooting is carried out in Białowieża Primeval Forest. Sport hunting is utilized in Borecka Forest and Bieszczady Mountains; selectivereductive shooting allows both regulation of numbers and improvment of the quality of the population by removal of weak and sick individuals, and aggressive or late calving females. Success requires much human effort during the selection and elimination of the animals.

Utilization of hunting requires much less work and gives material profits, but it is necessary to set maximum limits. It also needs to be effectively planned, and should be adjusted every year according to the state of the population and its age-sex structure.

Hunting carried out in Borecka Forest adversely influenced the population structure in some periods. For example in 1983 an increased number of young and a decreased number of adult cows occurred. These irregularities were removed by elimination of individuals from different age-sex classes. It appears that selective-reductive shooting together with limited hunting utilization is the best method for regulating the numbers of bison living in free populations.

There were some mistakes in the past in managing the European bison population in Borecka Forest. The natural population development was disturbed by introducting animals from other breeding centres, and sport-shooting was mismanaged. However regulation of the numbers of this herd is necessery to preserve a balance in the forest ecosystems.

Borecka Forest is a good place for breeding European bison in freedom because of it large area and density, variety and abundance of plants, and accessible fresh water springs. All these features create favourable conditions for the bison's 
existence. Borecka Forest is also very important in the process of distributing and increasing the living area of the lowland line of European bison because all the bison of this line contribute only $35 \%$ of the world population (Pucek 1989).

\section{Practical conclusions}

The large area and abundant habitats of Borecka Forest create conditions favourable to increasing the number of bison up to 70 individuals. Sport hunting can then be increased.

Hunting should be controlled and concern mainly selected specimens. Shooting of bulls and cows of a reproductive age are inadmissible. The profits made from shooting should be reserved for the upkeep of bison. Supplies of bison from the other breeding areas should be stopped.

Protection of stands and limitation of damage in cultivated fields could be accomplished by increasing the quality of supplemental feeding, optimizing the numbers of ungulates and preserving the correct age-sex structure of the population. The basis supplemental feeding should constitute hay of a good quality. Enclosing the bison from the free-ranging herd in the reserve to limit damage in the forest performed (done towards the end of winter until 1986) should be stopped.

An increase in feeding grounds could be accomplished by managing the feeding glades, mowing in-woodland meadows and assigning the cultivated fields near Diabla Góra to the bison's needs.

Acknowledgements: The authors wish to express their thanks to ing. Aleksander Stachurski and ing. Jerzy Stachurski, to ing. S. Olas, S. Makaus from Borki and also to dr K. Caboń- Raczyńska, ing. J. Dackiewicz from Białowieża for their help with collecting the material for this paper. Much thanks is due to Professor Z. Pucek for his general suggestions and critical reading of the first draft of this paper. Dr M. Meagher of Yellowstone National Park kindly much improved style of this paper. This study was partly supported by KBN project No 663689102 .

\section{References}

Bojanus H. L. 1827. De uro nostrate eiusque sceleto commentatio. Nova Acta phys.-med. Acad. Caes. Leopold. -Carol. Nat. Curios. 23: 413 - 478. Bonnae.

Dzięciołowski R.M. 1991. Ecological niches of five big ungulates in a forest tract. Folia Forestalia Polonica. Series A - Forestry 33: 56 - 70.

Krasińska M., Cabon-Raczyńska K. and Krasiński Z. A. 1987. Strategy of habitat utilization by European bison in the Białowieża Forest. Acta theriol. 32: $147-202$.

Krasińska M. and Krasiński Z. A. 1991. Strategie der Benuzung des Habitats von Bullen der Wisente im Urwald von Białowieża. Seevögel, Zeitschrift Verein Jordsand, Hamburg 12: 63 - 66.

Krasiński Z. A. 1978. Dynamics and structure of the European bison population in the Białowieża Primeval Forest. Acta theriol. 23: $13-48$.

Krasiński Z. A. 1986. Reserve breeding of European bison in Borecka Forest. Parki nar. Rez. przyr. 7: 73 - 79. [In Polish with English summary]

Ortwein L. 1960. Zubry w Puszczy Boreckiej. Chrońmy Przyr. ojcz. 16, 5: 17 - 20.

Polakowski B. 1961: Zespoły lesne Puszczy Boreckiej ze szczególnym uwzględnieniem leśnictwa Walisko i Lipowo. Studia Soc. scient. Toruniensis. 5: 1 - 146. 
Pucek Z., Bobek B., Labudzki L., Miłkowski L., Morow K. and Tomek A. 1975. Estimates of density and number of ungulates. Pol. ecol. Stud. 1: $121-136$.

Pucek Z. 1989. Die Rettung des Wisentes. Probleme der Verhaltung einer Art. [In: Die Illusion der Arche Noach. E. Schneider, H. Oetke and H. Gross, eds]. Echo Verlag Göttingen: 249 - 268.

Senger J. 1983. [Territory, numbers and behaviur of free-ranging European bison in Borecka Forest]. MTheses, Warsaw Agricultural University, Warszawa: 1 - 56.

Received 2 July 1991, revised 2 March 1992, accepted 22 May 1992.

Acta Theriologica 37 (3): 317, 1992.

\section{BOOKS RECEIVED}

WILK [THE WOLF]. H. Okarma. Białowieża, 1992. 168 pp. Price 4 USD. (Available from the Author, c/o Mammal Research Institute, Polish Academy of Sciences, 17-230 Białowieża, Poland. ISBN 83-900635-0-6.

This is a popular monograph of the species, decribing its biology, ecology and management. Chapters on human attitute to the wolf, including hunting techniques in east Europe, captive breeding and conservancy measures address the book to wide sphere of readers. Text in Polish is supplemented by a chapter in English - "The wolf in Poland", containing concise information on the status and biology of this predator in Poland.

POLISH RED DATA BOOK OF ANIMALS. Z. Głowaciński, ed. PWRiL - State Publishing House for Agriculture and Forestry, Warszawa, 1992. 352 pp. Price ca 15 USD. ISBN 83-09-01520-8.

Among included there are the following 32 species of mammals: Sorex caecutiens (R), Neomys anomalus (R), Rhinolophus hipposideros (E), Myotis bechsteini (V), Myotis emarginatus (E), Vespertilio murinus (R), Eptesicus nilssoni (R), Nyctalus leisleri (R), Lepus timidus (R), Citellus citellus (I), Citellus suslicus (V), Marmota marmota (E), Castor fiber (O), Pitymys tatricus (R), Microtus nivalis (R), Sicista betulina (R), Eliomys quercinus (I), Dryomys nitedula (R), Glis glis (R), Phocoena phocoena (I), Ursus arctos (R), Canis lupus (R), Lutra lutra (R), Mustela eversmanni (R), Mustela lutreola (ExP), Lynx lynx (R), Felis silvestris (E), Halichoerus grypus (I), Equus gmelini (Ex), Bison bonasus (O), Bos primigenius (Ex), Rupicapra rupicapra (R). Texts are in Polish, with summaries in English. 